\title{
Rapid photoprotection in sea-ice diatoms from the East Antarctic pack ice
}

\author{
Katherina Petrou, ${ }^{a}$ Ross Hill, ${ }^{\mathrm{a},}{ }^{*}$ Christopher M. Brown, ${ }^{\mathrm{b}, 1}$ Douglas A. Campbell, ${ }^{\mathrm{b}}$ \\ Martina A. Doblin, ${ }^{a}$ and Peter J. Ralpha \\ a Plant Functional Biology and Climate Change Cluster and Department of Environmental Sciences, University of Technology, \\ Sydney, Australia \\ ${ }^{\mathrm{b}}$ Department of Biology, Mount Allison University, Sackville, New Brunswick, Canada
}

\begin{abstract}
Photoinhibition and D1 protein re-synthesis were investigated in bottom-dwelling sea-ice microalgal communities from the East Antarctic pack ice during early spring. Bottom-dwelling sea-ice microalgal communities were dominated by diatoms that exhibited rapid photoprotection when exposed to a range of different light levels $\left(10 \mu \mathrm{mol}\right.$ photons $\mathrm{m}^{-2} \mathrm{~s}^{-1}, 50 \mu \mathrm{mol}$ photons $\mathrm{m}^{-2} \mathrm{~s}^{-1}, 100 \mu \mathrm{mol}$ photons $\mathrm{m}^{-2} \mathrm{~s}^{-1}$, and $200 \mu \mathrm{mol}$ photons $\mathrm{m}^{-2} \mathrm{~s}^{-1}$ ). Photosynthetic capacity of photosystem II (PSII) dropped significantly over $3 \mathrm{~h}$ under $200 \mu \mathrm{mol}$ photons $\mathrm{m}^{-2} \mathrm{~s}^{-1}$, but largely recovered when placed in a low-light environment (10 $\mu$ mol photons $\mathrm{m}^{-2} \mathrm{~s}^{-1}$ ) for an additional $3 \mathrm{~h}$. PSII repair rates increased with increasing irradiance, and the D1-protein pool remained steady even under high light $\left(200 \mu \mathrm{mol}\right.$ photons $\left.\mathrm{m}^{-2} \mathrm{~s}^{-1}\right)$. Sea-ice diatoms showed a low intrinsic susceptibility to photoinactivation of PSII across all the light treatments, and a strong and irradiance-dependent induction of nonphotochemical quenching, which did not depend upon chloroplast protein synthesis, was also seen. These highly plastic organisms, once thought to be adapted to shade, are in fact well equipped to withstand rapid and relatively large changes in light at low temperatures with minimal long-term effect on their photosynthetic machinery.
\end{abstract}

Warming is occurring throughout the global ocean (Levitus et al. 2005; Domingues et al. 2008), posing a serious challenge to all marine ecosystems. High-latitude sea-ice ecosystems are among the environments most susceptible to the effects of increasing oceanic and atmospheric temperatures, with observed declines in seaice thickness (Giles et al. 2008) and extent (Turner et al. 2005; Serreze et al. 2007) already recorded at both poles. Indeed, the West Antarctic has experienced the greatest warming on the planet $\left(0.56-1.09^{\circ} \mathrm{C}\right.$ decade $\left.^{-1}\right)$ over the last $30 \mathrm{yr}$ (Turner et al. 2005, 2006). It is projected that continued warming over both polar regions will lead to further reductions in the duration, thickness, and extent of the annual sea ice (Mayewski et al. 2009), and to changes in snowfall patterns, with precipitation increasing in some areas and declining in others (IPCC 2007). These changes in sea-ice conditions will affect the light climate within the sea ice and hence will affect photosynthesis in bottomdwelling sea-ice microalgal communities.

The ephemeral sea ice is a defining structural feature of the Antarctic ecosystem (Eicken 1992), and its annual cycle of formation and decay is the major process that drives global thermohaline circulation. Antarctic sea ice provides a niche for a diverse microbial community of bacteria, microalgae, and protists, which in turn provide a vital food source for higher trophic levels during the winter months, when food and sunlight are scarce. Like all photoauto-

\footnotetext{
*Corresponding author: ross.hill@uts.edu.au
}

${ }^{1}$ Present address: Environmental Biophysics and Molecular Ecology Group, Institute of Marine and Coastal Sciences, Rutgers, The State University of New Jersey, New Brunswick, New Jersey trophs, sea-ice microalgae must balance light energy entering their photosystems with the energy utilized in carbon fixation (Ensminger et al. 2006). However, unlike most photosynthetic organisms, sea-ice microalgae have to maintain this balance under cold, hypersaline, and often hyperoxic conditions (Thomas and Dieckmann 2002; Morgan-Kiss et al. 2006). In higher plants, low temperatures often result in an increase in relative excitation pressure on photosystem II (PSII), particularly in conjunction with high light (Hüner et al. 1993; Hüner 1998; Ivanov et al. 2003). In response to short-term light stress, nonphotochemical quenching (NPQ) of chlorophyll $a$ fluorescence is activated. This substantially reduces the effective absorption cross section of PSII to limit overexcitation of the photosystem. Overexcitation of PSII can result in the production of reactive oxygen species in the thylakoid lumen (Müller et al. 2001), causing light-induced damage to the photosynthetic apparatus. Photoinactivation is the primary event that leads to a loss of activity in PSII reaction centers (Nagy et al. 1995; Six et al. 2007; Key et al. 2010). A common site of damage is the D1 protein of PSII (Aro et al. 1993; Tyystjarvi 2008). If the rate of photoinactivation exceeds the rate of protein repair (Aro et al. 1993; Melis et al. 1999), photoinhibition of photosynthesis results because the pool of active PSII centers declines. The extent of photoinhibition is thus dependent on the dynamic balance between the rate of PSII protein photoinactivation and the rate of PSII repair through proteolytic removal of the photoinactivated D1 and resynthesis of a replacement D1 protein. Because photoinactivation is driven by the level of incident light, but the repair is metabolic (which is temperature sensitive), photoinactivation and repair can become imbalanced with decreasing temperature, leading to photoinhibition. In this 
way, the cycle of D1-protein breakdown and resynthesis is important to maintain PSII function under potentially photoinhibiting conditions (Allakhverdiev and Murata 2004).

Although psychrophilic microalgae have evolved metabolic strategies to photosynthesize and grow at low temperatures (Morgan-Kiss et al. 2006), little is known about how they acclimate to increases in irradiance and what photoprotective mechanisms they employ under such circumstances. Previous studies from both polar regions have found bottom-dwelling sea-ice microalgae to have great capacity for low-light acclimation (Lizotte and Sullivan 1991; Thomas et al. 1992), and they are thus described as shade adapted (Cota 1985; Palmisano et al. 1985). However, a recent investigation into photoprotection with a laboratory culture of the diatom Fragilariopsis cylindrus, a dominant bipolar sea-ice microalgal species, showed a high capacity for NPQ under moderately high light exposure $(250 \mu \mathrm{mol}$ photons $\mathrm{m}^{-2} \mathrm{~s}^{-1}$ ) (Kropuenske et al. 2009), suggesting that sea-ice microalgae possess high-light photoprotective capabilities. Developing an understanding of the physiological plasticity of sea-ice microalgae is of particular importance when trying to predict their capacity for acclimation to rapid environmental change, specifically the increased irradiances expected with predicted ice thinning.

To date, there have been no studies on photoinhibition of Antarctic bottom-dwelling sea-ice microalgal communities. Therefore, the main purpose of this study was to determine whether these organisms, previously assumed to be shade adapted (Cota 1985; Palmisano et al. 1985; Thomas and Dieckmann 2002), are indeed susceptible to photoinhibition in the early spring, within the context of predictions for thinning sea-ice conditions in a warmer climate. The hypothesis, that bottom-dwelling Antarctic sea-ice microalgae are able to avoid photoinhibition through rapid photoprotective mechanisms, was tested.

\section{Methods}

Sample collection and experimental protocol-Sea-ice microalgae were collected in Austral spring (September and October 2007) from four different locations $(n=4)$ in the East Antarctic pack ice (from $64.24^{\circ} \mathrm{S}$ to $65.35^{\circ} \mathrm{S}$ and $121.31^{\circ} \mathrm{E}$ to $128.05^{\circ} \mathrm{E}$ ) during the Sea Ice Physics and Ecosystem eXperiment (SIPEX) voyage aboard the R/V Aurora Australis. Measurements were made twice at the first location and then once at each of the following three sites. D1-protein determinations were made on samples collected from only the final three sites $(n=3)$ due to very low biomass at the first location. Ice-core thickness varied from $47 \mathrm{~cm}$ to $130 \mathrm{~cm}$, with measured ambient light ranging from around $2.3 \mu \mathrm{mol}$ photons $\mathrm{m}^{-2} \mathrm{~s}^{-1}$ to $57 \mu \mathrm{mol}$ photons $\mathrm{m}^{-2} \mathrm{~s}^{-1}$, depending on ice thickness, snow cover, and incident irradiance. Under-ice photosynthetically active radiation (PAR) was measured using a $2 \pi$ underwater sensor (LI-189, LICOR) connected to a mechanical arm. Thus measurements were made at a 2-m distance from the core hole in order to avoid direct sunlight intrusion. Measurements were made hourly from 12:00 h until 18:00 h. Bottom-dwelling sea-ice microalgae were collected using

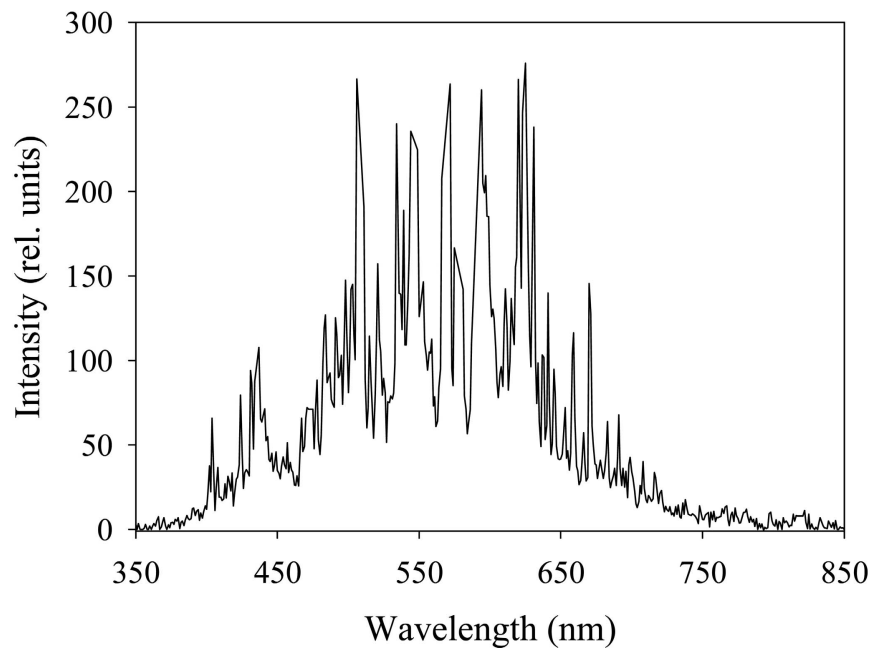

Fig. 1. The relative spectrum of light between the wavelengths of 350-850 nm emitted from the metal halide light source. Spectral output was measured through polyethylene jars and water.

an ice auger (internal diameter: $90 \mathrm{~mm}$ ), and the bottom $20 \mathrm{~mm}$ of the core was then sawed off under black plastic and melted in filtered $(0.22 \mu \mathrm{m})$ seawater and brine over $24 \mathrm{~h}$ at $4{ }^{\circ} \mathrm{C}$ in the dark. To avoid osmotic stress, salinity was checked every $5 \mathrm{~h}$ to ensure that salinity remained within the range of 30 to 35 . If salinity dropped lower than 30 during melting, more filtered brine (salinity 75) was added. Brine water was extracted by means of the incomplete coring of holes in the sea ice and by collecting the hypersaline interstitial sea-ice water that filled the cored hole. Before experimental procedures began, a $5-\mathrm{mL}$ aliquot of microalgal sample was preserved in $1 \%$ glutaraldehyde for later microscopic cell identification and size determination.

Aliquots of melted ice cores $(70 \mathrm{~mL})$ were subsampled into 16 clear, standard, polyethylene jars. Half of the jars were treated with $500 \mu \mathrm{g} \mathrm{mL}^{-1}$ of the chloroplast protein synthesis inhibitor lincomycin (Aro et al. 1993; Singleton and Sainsbury 1994), and the remaining half were left untreated. Maximum quantum yield of PSII was measured in all samples prior to the jars being placed into one of four light treatments $\left(10 \mu \mathrm{mol}\right.$ photons $\mathrm{m}^{-2} \mathrm{~s}^{-1}, 50 \mu \mathrm{mol}$ photons $\mathrm{m}^{-2} \mathrm{~s}^{-1}, 100 \mu \mathrm{mol}$ photons $\mathrm{m}^{-2} \mathrm{~s}^{-1}$, or $200 \mu \mathrm{mol}$ photons $\mathrm{m}^{-2} \mathrm{~s}^{-1}$ ), with subsequent measurements being made after $0.5 \mathrm{~h}, 1 \mathrm{~h}, 2 \mathrm{~h}$, and $3 \mathrm{~h}$. Light was supplied by a metal halide lamp (Osram), and light levels were adjusted using neutral density filters (Lee Filters). The spectral quality during the incubation (see Fig. 1 for photon emission spectra) was measured using a spectrophotometer (Ocean Optics). Jars containing melted algal samples were incubated in a custom-built flow-through chamber maintained at $-1.8^{\circ} \mathrm{C}$. Following the 3 -h exposure period, all jars were placed into the lowest light treatment $(10 \mu \mathrm{mol}$ photons $\mathrm{m}^{-2} \mathrm{~s}^{-1}$ ) and were left for a further $3 \mathrm{~h}$ before being tested for photosynthetic recovery.

Chlorophyll a fluorescence - Chlorophyll a fluorescence measurements were made using a Water-PAM (Pulse 
Amplitude Modulated) Fluorometer (Walz, GmbH). Subsamples $(3 \mathrm{~mL})$ from each jar were transferred at each time point into a quartz cuvette and were dark-adapted for 10 min before measuring maximum quantum yield of PSII $\left(F_{V}: F_{M}\right)$ (measuring light frequency $=6$; photomultiplier gain $=10-26$ (depending on algal density); output gain $=$ 1 ; damping $=1$; saturating pulse intensity $>3000 \mu \mathrm{mol}$ photons $\mathrm{m}^{-2} \mathrm{~s}^{-1}$; and saturating pulse width $=0.6 \mathrm{~s}$ ). A 10-min dark-adaptation period was chosen as the minimum time required to reach maximum $\mathrm{F}_{\mathrm{M}}$, based on prior measurements of different time intervals. Maximum quantum yield of PSII was calculated as the difference between the minimum fluorescence value $\left(\mathrm{F}_{\mathrm{O}}\right)$ and the maximum fluorescence value $\left(\mathrm{F}_{\mathrm{M}}\right)$ (i.e., $\mathrm{F}_{\mathrm{M}}-\mathrm{F}_{\mathrm{O}}=\mathrm{F}_{\mathrm{V}}$ ) and divided by $\mathrm{F}_{\mathrm{M}}$ : $\left(\mathrm{F}_{\mathrm{M}}-\mathrm{F}_{\mathrm{O}}\right) / \mathrm{F}_{\mathrm{M}}$ (Schreiber 2004).

D1-protein determination-For D1-protein (encoded by the psbA gene) determination, samples were taken initially and after $3 \mathrm{~h}$ of light exposure for comparison of protein levels. Samples were filtered onto 47-mm-diameter glass microfiber (GF/F) filters (Whatman), placed in a $2-\mathrm{mL}$ cryovial, and frozen at $-80^{\circ} \mathrm{C}$ for later analysis. Protein quantification was performed using the protein extraction method and immunoblotting techniques described in Six et al. (2007) and Brown et al. (2007, 2008). The anti-psbA antibody for D1 detection and protein quantification standard (www.agrisera.com) were used to immunodetect and quantify D1 levels.

Determination of PSII photoinactivation and repair rates-For parameterization of photoinactivation during the exposure period, we estimated an effective target size for photoinactivation $\left(\sigma_{\mathrm{i}}\right.$ with units of $\left.\mathrm{nm}^{2} \mathrm{PSII}^{-1}\right)$ as the exponential decay rate of $\mathrm{F}_{\mathrm{V}}: \mathrm{F}_{\mathrm{M}}$ plotted vs. the cumulative photon dose (Six et al. 2007) incident on the algal suspensions in the presence of lincomycin. The $\mathrm{F}_{\mathrm{V}}: \mathrm{F}_{\mathrm{M}}$ value at $0.5 \mathrm{~h}$ was used as the initial $100 \% \mathrm{~F}_{\mathrm{V}}: \mathrm{F}_{\mathrm{M}}$ value (Six et al. 2007). This allowed better separation of the change in $\mathrm{F}_{\mathrm{V}}: \mathrm{F}_{\mathrm{M}}$ as a result of the cumulative absorption of photons during the photoinactivation phase from those during the initial phase dominated by induction of NPQ. The $\left|\sigma_{\mathrm{i}}\right|$ parameterization allowed estimation of the photoinactivation rate by multiplying $\left|\sigma_{\mathrm{i}}\right|$ with incident irradiance (photons $\mathrm{m}^{-2} \mathrm{~s}^{-1}$ ). $\left|\sigma_{\mathrm{i}}\right|$ was not the physical size of an entity, but rather it expressed, in units of nominal area per PSII, the probability that a photon incident upon the algae community caused the photoinactivation of a PSII center. Repair rates of PSII were estimated using the difference in exponential decay rates of $\mathrm{F}_{\mathrm{V}}: \mathrm{F}_{\mathrm{M}}$ plotted against time in the absence and presence of lincomycin (Six et al. 2007; Key et al. 2010), starting after an initial 0.5-h period when induction of rapid NPQ processes dominated the responses. The ability to acclimate to increased irradiance depends on the rate of PSII repair $\left(R_{\mathrm{PSII}} \mathrm{s}^{-1}\right)$, which must either equal or exceed photoinactivation rates in order to avoid photoinhibition.

Data analysis - Quantification of D1 immunoblots was performed using a charge-coupled device (CCD) imager (Kodak Carestream 4000MMPro) and associated software
(Carestream Molecular Imaging). Changes in $\mathrm{F}_{\mathrm{V}}: \mathrm{F}_{\mathrm{M}}$ and D1-protein level were analyzed by a temporally dependent, general linear model ANOVA with three fixed factors (i.e., time, light, and lincomycin) in conjunction with a Tukey's post hoc pairwise comparison $(\alpha=0.05)$. One-way ANOVA was used to detect differences in the $R_{\mathrm{PSII}}$ rate among light treatments $(\alpha=0.05)$. To ensure that assumptions of normality and equal variance for both parametric tests were satisfied, the Kolmogorov-Smirnov test for normality and Levene's test for homogeneity of variance were applied to all analyses. In all cases the assumptions were met. Analyses were performed using Minitab statistical software (version 15.1.0.0 2006).

\section{Results}

Microscopic analyses of the preserved sea-ice microalgal communities revealed a fairly homogeneous community of pennate diatoms consisting almost entirely of members of the genus Fragilariopsis, falling into two cell-volume categories: small $\left(1.0 \pm 0.22 \times 10^{3} \mu \mathrm{m}^{3}\right)$ and large $(1.8 \pm$ $\left.0.09 \times 10^{3} \mu \mathrm{m}^{3}\right)$. Statistical analyses of the $\mathrm{F}_{\mathrm{V}}: \mathrm{F}_{\mathrm{M}}$ and D1protein data showed no significant interactions between time, light, and lincomycin. However, individual factors of time, light, and lincomycin were significant $(p<0.001, p<$ 0.001 , and $p=0.007$, respectively) for the $100 \mu \mathrm{mol}$ photons $\mathrm{m}^{-2} \mathrm{~s}^{-1}$ and $200 \mu \mathrm{mol}$ photons $\mathrm{m}^{-2} \mathrm{~s}^{-1}$ light treatments, as determined by the ANOVA with post-hoc comparison. The sea-ice microalgae exposed to $10 \mu \mathrm{mol}$ photons $\mathrm{m}^{-2} \mathrm{~s}^{-1}$ or $50 \mu \mathrm{mol}$ photons $\mathrm{m}^{-2} \mathrm{~s}^{-1}$ showed no significant change in $\mathrm{F}_{\mathrm{V}}: \mathrm{F}_{\mathrm{M}}$ over the 6-h incubation period, and no statistically significant difference between the lincomycin and non-lincomycin control treatments (Fig. 2a,b) was evident. At $100 \mu$ mol photons $\mathrm{m}^{-2} \mathrm{~s}^{-1} \mathrm{a}$ significant decline in $\mathrm{F}_{\mathrm{V}}: \mathrm{F}_{\mathrm{M}}(p<0.001)$ from approximately 0.60 to 0.40 after $3 \mathrm{~h}$ was observed; however, no significant difference between the control cells and the lincomycin-treated cells was detected (Fig. 2c). The highest light treatment $\left(200 \mu \mathrm{mol}\right.$ photons $\left.\mathrm{m}^{-2} \mathrm{~s}^{-1}\right)$ showed a significant decline in $\mathrm{F}_{\mathrm{V}}: \mathrm{F}_{\mathrm{M}}$ from 0.60 to 0.35 in the control treatment, and $\mathrm{F}_{\mathrm{V}}: \mathrm{F}_{\mathrm{M}}$ declined to 0.26 in the presence of lincomycin $(p<0.001)$ after $3 \mathrm{~h}$ (Fig. 2d). Here, a significant difference between the control and lincomycintreated samples $(p=0.007)$ was detected. In the two highest light treatments, most of the observed drop in $\mathrm{F}_{\mathrm{V}}: \mathrm{F}_{\mathrm{M}}$ occurred within the first $0.5 \mathrm{~h}$, with a subsequent slower phase over the remainder of the treatment. Furthermore, in the high light treatment $\left(200 \mu \mathrm{mol}\right.$ photons $\left.\mathrm{m}^{-2} \mathrm{~s}^{-1}\right)$, the subsequent recovery of $\mathrm{F}_{\mathrm{V}}: \mathrm{F}_{\mathrm{M}}$ in the absence of lincomycin reached $0.50,84 \%$ of the initial value. In contrast, the $\mathrm{F}_{\mathrm{V}}: \mathrm{F}_{\mathrm{M}}$ in the lincomycin-treated microalgae recovered to 0.37 (only $61 \%$ of the initial value) after $3 \mathrm{~h}$ of recovery light (10 $\mu$ mol photons $\left.\mathrm{m}^{-2} \mathrm{~s}^{-1}\right)$ (Fig. $2 \mathrm{~d}$ ).

Changes in D1-protein levels followed the patterns observed in the chlorophyll fluorescence data (Fig. 2a-d). Under high light $\left(200 \mu\right.$ mol photons $\left.\mathrm{m}^{-2} \mathrm{~s}^{-1}\right)$ the lincomycin-treated cells showed a decline in D1-protein content from $0 \mathrm{~h}$ to $3 \mathrm{~h}$ that was at the edge of significance ( $p=0.052$; paired, one-tailed $t$-test, $n=3$ ). At $3 \mathrm{~h}$, the D1 content was significantly lower in the lincomycin-treated 


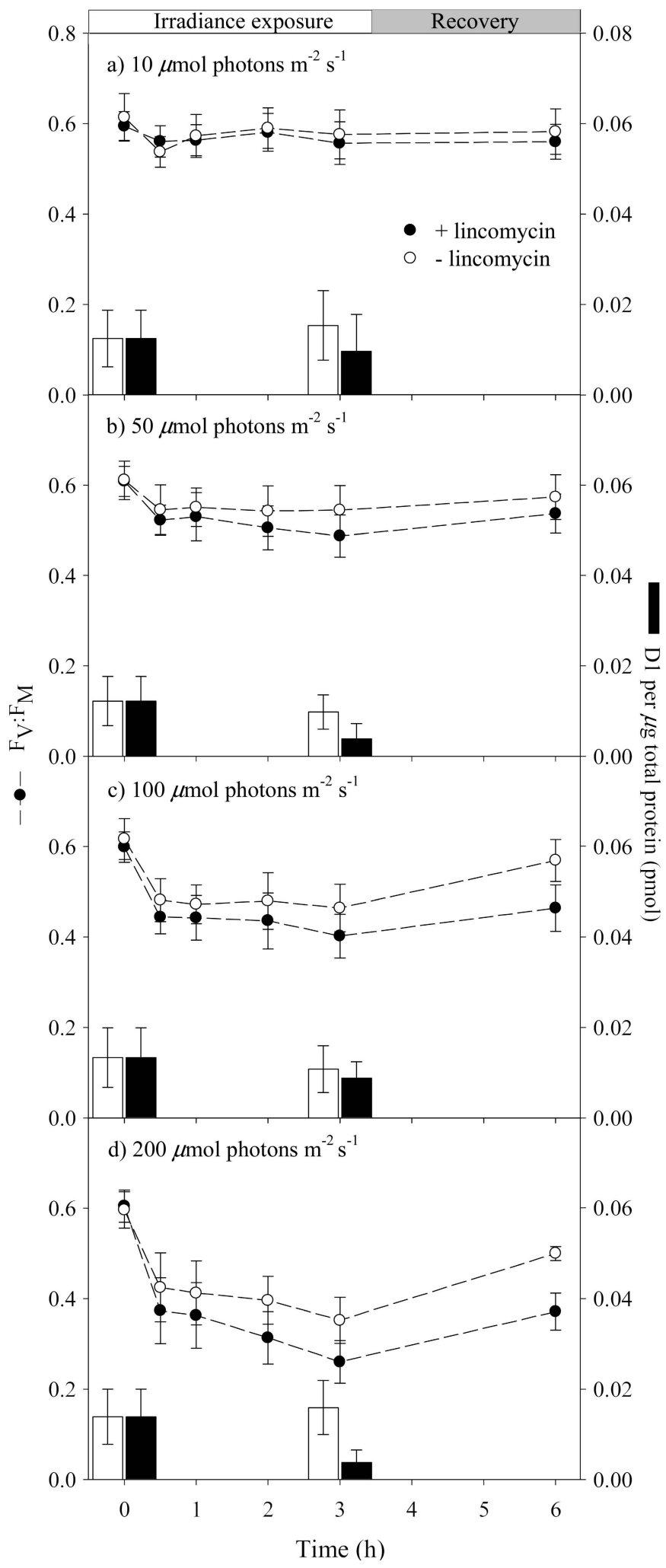

Fig. 2. Maximum quantum yield of PSII $\left(\mathrm{F}_{\mathrm{V}}: \mathrm{F}_{\mathrm{M}}\right)$ of sea-ice microalgal communities in the presence (closed circles) and absence (open circles) of lincomycin exposed to (a) $10 \mu \mathrm{mol}$ photons $\mathrm{m}^{-2} \mathrm{~s}^{-1}$, (b) $50 \mu \mathrm{mol}$ photons $\mathrm{m}^{-2} \mathrm{~s}^{-1}$, (c) $100 \mu \mathrm{mol}$ photons $\mathrm{m}^{-2} \mathrm{~s}^{-1}$, and (d) $200 \mu \mathrm{mol}$ photons $\mathrm{m}^{-2} \mathrm{~s}^{-1}$. Samples were exposed to light conditions for $3 \mathrm{~h}$ followed by $3 \mathrm{~h}$ of recovery light $\left(10 \mu \mathrm{mol}\right.$ photons $\left.\mathrm{m}^{-2} \mathrm{~s}^{-1}\right)$. Data represent means cells than in the control cells ( $p=0.018$; paired, one-tailed $t$-test, $n=3$ ). This demonstrates that the control cells synthesize D1 in sufficient amounts to counter the loss from the D1 pool that was observed in the lincomycintreated cells. In the other light and inhibitor treatments the changes in D1 protein were not large enough to reach statistical significance.

The effective target size for photoinactivation of PSII, $\left|\sigma_{\mathrm{i}}\right|$, was comparable when estimated for each light level separately (Allakhverdiev and Murata 2004). Therefore, the data from the four light treatments were pooled for an overall estimate of $\left|\sigma_{\mathrm{i}}\right|$ prevailing across the range of treatment lights (Fig. 3). The functional repair rate of PSII $\left(R_{\mathrm{PSII}}\right)$ was estimated as the difference in the exponential decay rates for $\mathrm{F}_{\mathrm{V}}: \mathrm{F}_{\mathrm{M}}$ in the absence and presence of lincomycin (Fig. 4), which blocks D1 repair. $R_{\mathrm{PSII}}$ was not determined in the light level of the control; it was not detectable. However, when comparing the other light levels, there was a significant increase from $8.55 \times 10^{-6}(50 \mu \mathrm{mol}$ photons $\left.\mathrm{m}^{-2} \mathrm{~s}^{-1}\right)$ to $2.27 \times 10^{-5}$ PSII s$^{-1}(p=0.006)$ when measured under the highest irradiance (Table 1). The repair rates achieved $\left(R_{\mathrm{PSII}}\right)$ were faster than the estimated rate of photoinactivation $\left|\sigma_{\mathrm{i}}\right| \times$ irradiance $(E)$ under the three determined light treatments (Table 1).

\section{Discussion}

Antarctic sea-ice diatoms from the East Antarctic show rapid photoprotection when exposed to high-light conditions, responding with an irradiance-dependent initial decline in the maximum quantum yield of PSII $\left(\mathrm{F}_{\mathrm{V}}: \mathrm{F}_{\mathrm{M}}\right)$ within $0.5 \mathrm{~h}$ following the increase in illumination. We hypothesize that this initial, rapid, irradiance-dependent drop in $F_{V}: F_{M}$ represents an induction of NPQ to dissipate excess excitation energy (Kropuenske et al. 2009). Subsequent to the initial $0.5 \mathrm{~h}$, the cells showed a further, slower decline in $\mathrm{F}_{\mathrm{V}}: \mathrm{F}_{\mathrm{M}}$, which was negligible in low light but was detectable in higher light. When cells were returned to low light, they showed some recovery within $3 \mathrm{~h}$, demonstrating their photosynthetic resilience to changes in light environment. The recovery observed in control samples can be attributed to both PSII repair and relaxation of NPQ processes, whereas the recovery in the lincomycin-treated cells is solely due to the decline in NPQ because PSII repair was blocked. It is clear from this study that some of these highly plastic organisms, once thought to be shade adapted (Cota 1985; Palmisano et al. 1985; Thomas and Dieckmann 2002), are in fact well equipped to deal with rapid and relatively large changes in light level $(10 \mu \mathrm{mol}$ photons $\mathrm{m}^{-2} \mathrm{~s}^{-1}$ to $200 \mu \mathrm{mol}$ photons $\left.\mathrm{m}^{-2} \mathrm{~s}^{-1}\right)$, even at low temperatures, with minimal lasting effects to their photosynthetic machinery.

( $n=5 \pm$ SEM). Vertical bars represent pmol of D1 $\mu \mathrm{g}^{-1}$ of total protein in sea-ice microalgal communities in the presence (black bars) and absence (white bars) of lincomycin exposed to $10 \mu \mathrm{mol}$ photons $\mathrm{m}^{-2} \mathrm{~s}^{-1}, 50 \mu \mathrm{mol}$ photons $\mathrm{m}^{-2} \mathrm{~s}^{-1}, 100 \mu \mathrm{mol}$ photons $\mathrm{m}^{-2} \mathrm{~s}^{-1}$, and $200 \mu \mathrm{mol}$ photons $\mathrm{m}^{-2} \mathrm{~s}^{-1}$ (a-d, respectively) at $0 \mathrm{~h}$ and $3 \mathrm{~h}$ of exposure. Data represent means $(n=3 \pm \mathrm{SEM})$. 


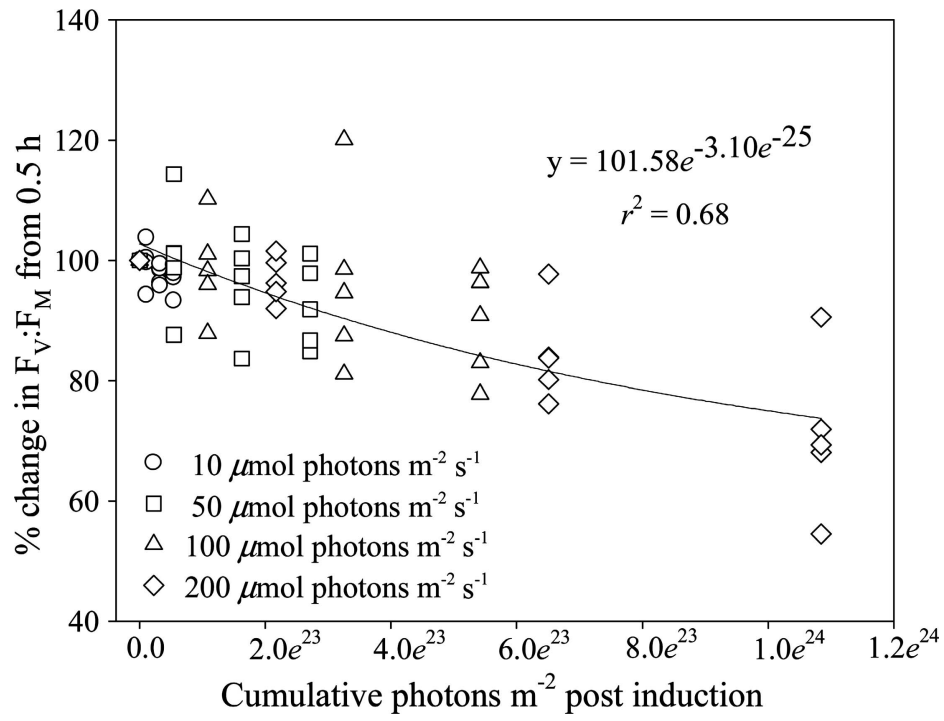

Fig. 3. Percentage change in $\mathrm{F}_{\mathrm{V}}: \mathrm{F}_{\mathrm{M}}$ of sea-ice microalgae in the presence of lincomycin expressed as a function of cumulative photons postinduction for the light treatments of $10 \mu \mathrm{mol}$ photons $\mathrm{m}^{-2} \mathrm{~s}^{-1}, 50 \mu \mathrm{mol}$ photons $\mathrm{m}^{-2} \mathrm{~s}^{-1}, 100 \mu \mathrm{mol}$ photons $\mathrm{m}^{-2} \mathrm{~s}^{-1}$, and $200 \mu \mathrm{mol}$ photons $\mathrm{m}^{-2} \mathrm{~s}^{-1}$. Data have been fitted with an exponential decay function. Dots represent individual replicates.

During the 3-h exposure to the highest irradiance (200 $\mu$ mol photons $\mathrm{m}^{-2} \mathrm{~s}^{-1}$ ), the sea-ice diatoms showed an upregulation of their PSII repair rate at the highest irradiance (Table 1), which allowed them to maintain their pools of D1 protein (Fig. 2). The sea-ice diatom PSII repair rates were slower compared with diatoms of similar volume measured at temperate temperatures (Key et al. 2010). This is to be expected because lower temperatures slow down metabolic processes (Morgan-Kiss et al. 2006). Nevertheless, the sea-ice diatoms did induce measurable PSII repair, which kept pace with photoinactivation rates even at the highest irradiance tested, $200 \mu \mathrm{mol}$ photons $\mathrm{m}^{-2} \mathrm{~s}^{-1}$, which was many times higher than the measured light in their under-ice environment $\left(2.3 \mu \mathrm{mol}\right.$ photons $\mathrm{m}^{-2} \mathrm{~s}^{-1}$ to $57 \mu \mathrm{mol}$ photons $\mathrm{m}^{-2} \mathrm{~s}^{-1}$ ). Beyond modulation of PSII repair, two important factors contribute to the strong capacity of the sea-ice diatom community to withstand an increase in light. The sea-ice diatoms, like temperate diatoms (Key et al. 2010), show a low intrinsic susceptibility to PSII photoinactivation, which means that even modest PSII repair rates can keep pace with the limited photoinactivation across the range of light levels measured.

In parallel, the sea-ice diatoms show a significant, irradiance-dependent capacity to rapidly induce a reversible down-regulation of PSII within $0.5 \mathrm{~h}$ of a shift to increased light. This downregulation occurred in both the presence and absence of lincomycin, and was reversible to equivalent extents in the presence and absence of lincomycin, within $3 \mathrm{~h}$ after a return to low light. This mechanism thus does not depend upon contemporaneous chloroplastic protein synthesis, and shows a kinetic pattern that is likely associated with a NPQ mechanism. NPQ can enable cells to balance the total amount of absorbed energy with their capacity for utilization in metabolic activity, and thus serves to limit photo-oxidative damage (Ruban et al. 2004). Kropuenske et al. (2009) also found that in the sea-ice diatom Fragilariopsis cylindrus, the addition of lincomycin had no effect on patterns of NPQ induction and caused only a $5 \%$ decline in $\mathrm{F}_{\mathrm{V}}: \mathrm{F}_{\mathrm{M}}$ compared with a control treatment (Kropuenske et al. 2009). Similarly, minimal functional sensitivity to lincomycin was observed in the large diatom Coscinodiscus wailesii (Key et al. 2010). In all of these cases, NPQ and a high intrinsic resistance to photoinactivation allowed the diatoms to endure exposure to high light, even with modest PSII repair rates.

This photosynthetic pattern of diatoms contrasts with an Antarctic psychrophilic chlorophyte, Chlamydomonas raudensis (Pocock et al. 2007) isolated from Lake Bonney in the Taylor Valley, Antarctica, which depends heavily upon a rapid PSII repair cycle. In $C$. raudensis, PSII repair functions maximally at low temperatures $\left(8^{\circ} \mathrm{C}\right)$, generating unusually rapid recovery (given the low temperatures) from

Table 1. Photophysiological properties of sea-ice diatom communities under four light levels. $\left|\sigma_{\mathrm{i}}\right|$, effective target size of PSII photoinactivation; $R_{\text {PSII }}$, repair rate or PSII ( $n=3$, values in parentheses \pm SEM). n.d. $=$ not determined.

\begin{tabular}{|c|c|c|c|c|}
\hline & Control & Low & Medium & High \\
\hline Light levels ( $\mu$ mol photons $\mathrm{m}^{-2} \mathrm{~s}^{-1}$ ) & 10 & 50 & 100 & 200 \\
\hline$\left|\sigma_{\mathrm{i}}\right|\left(\mathrm{nm}^{2} \mathrm{PSII}^{-1}\right)$ & n.d. & $3.1 \times 10^{-7}\left(7.3 \times 10^{-5}\right)$ & $3.1 \times 10^{-7}\left(7.3 \times 10^{-5}\right)$ & $3.1 \times 10^{-7}\left(7.3 \times 10^{-5}\right)$ \\
\hline$R_{\text {PSII }}\left(\right.$ PSII s $\left.^{-1}\right)$ & n.d. & $8.55 \times 10^{-6}\left(2.14 \times 10^{-6}\right)$ & $8.57 \times 10^{-6}\left(3.57 \times 10^{-6}\right)$ & $2.27 \times 10^{-5 *}\left(4.58 \times 10^{-6}\right)$ \\
\hline Photoinactivation $(\mathrm{P})$ vs. repair $(\mathrm{R})$ & n.d. & $\mathrm{R} \geq \mathrm{P}$ & $\mathrm{R} \geq \mathrm{P}$ & $\mathrm{R} \geq \mathrm{P}$ \\
\hline
\end{tabular}

* Significantly different from all other light treatments at $p<0.01$. 


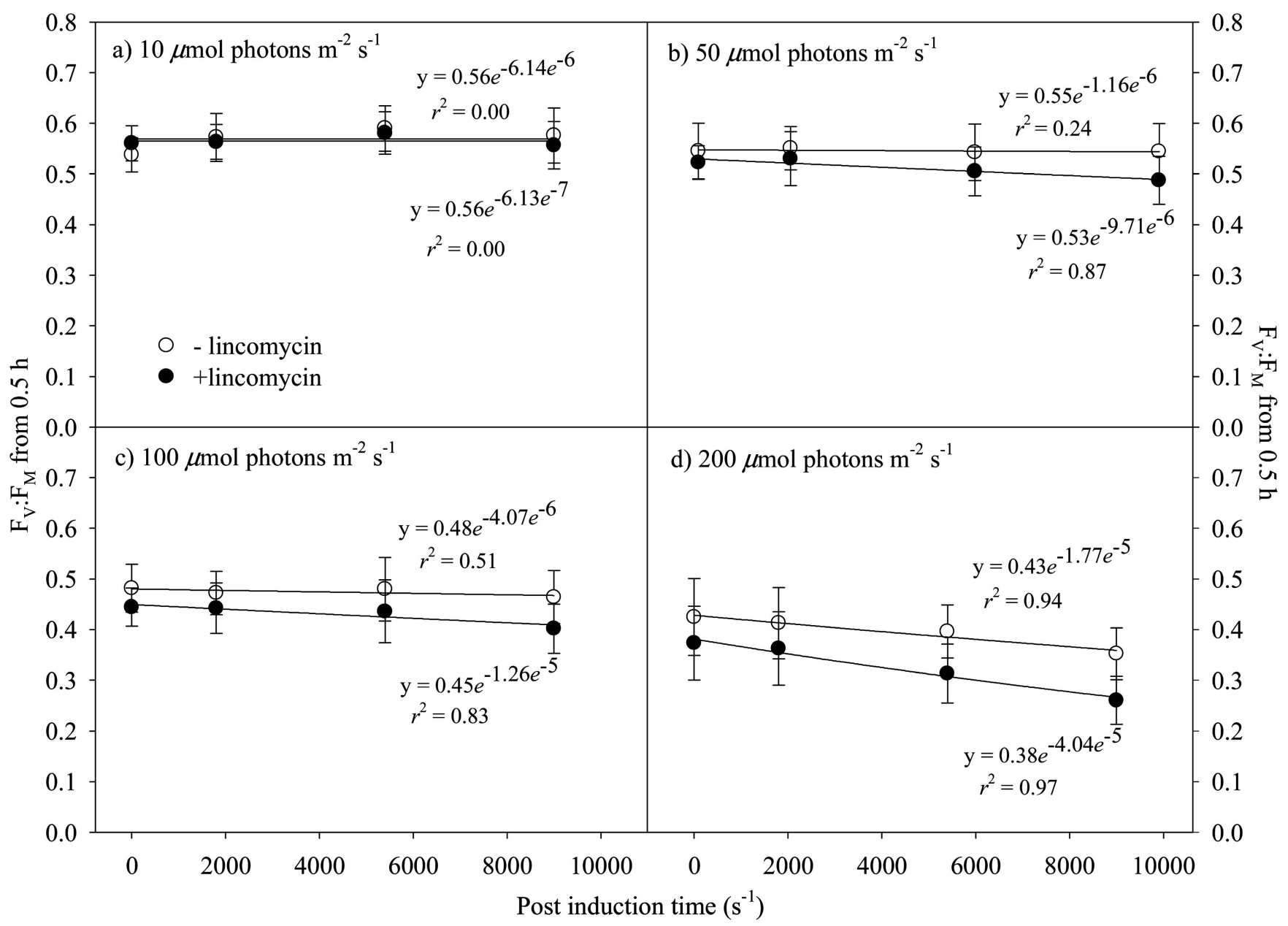

Fig. 4. Maximum quantum yield of PSII ( $\left.\mathrm{F}_{\mathrm{V}}: \mathrm{F}_{\mathrm{M}}\right)$ of sea-ice algae in the presence (closed circles) and absence (open circles) of lincomycin expressed as a function of time postinduction for the light treatments of (a) $10 \mu$ mol photons $\mathrm{m}^{-2} \mathrm{~s}^{-1}$, (b) $50 \mu$ mol photons $\mathrm{m}^{-2} \mathrm{~s}^{-1}$, (c) $100 \mu \mathrm{mol}$ photons $\mathrm{m}^{-2} \mathrm{~s}^{-1}$, and (d) $200 \mu \mathrm{mol}$ photons $\mathrm{m}^{-2} \mathrm{~s}^{-1}$. Data have been fitted with an exponential decay function. Differences in exponential decay rates of lincomycin and control samples were tested: decay rates were significantly different at $10 \mu$ mol photons $\mathrm{m}^{-2} \mathrm{~s}^{-1}$ and $50 \mu \mathrm{mol}$ photons $\mathrm{m}^{-2} \mathrm{~s}^{-1}(p=0.024$ and 0.012 , respectively), but no differences were found between the control and lincomycin decay rates at $100 \mu \mathrm{mol}$ photons $\mathrm{m}^{-2} \mathrm{~s}^{-1}$ and $200 \mu \mathrm{mol}$ photons $\mathrm{m}^{-2} \mathrm{~s}^{-1}$. Data represent means $(n=5$, SEM).

photoinhibition after high light exposure (Pocock et al. 2007). However, the irradiance used by Pocock et al. (2007) was three times greater $\left(600 \mu \mathrm{mol}\right.$ photons $\left.\mathrm{m}^{-2} \mathrm{~s}^{-1}\right)$ than the irradiance applied in this study. Furthermore, diatoms and chlorophytes such as $C$. raudensis may rely upon a different mechanism in response to changes in light (Six et al. 2009). The combination of limited PSII photoinactivation and a reasonably effective D1 protein resynthesis in these sea-ice diatoms explains the remarkable capacity for these supposedly shade-adapted psychrophiles to withstand higher light levels with limited long-term photodamage.

Cell size could also be an important factor in responses to increasing light because cell volume has been correlated with D1 repair rates across a range of temperate diatoms (Key et al. 2010; Six et al. 2009). In a recent study, small diatoms $\left(1.19 \times 10^{1} \mu \mathrm{m}^{3}\right)$ showed faster repair rates and greater photoinactivation (up to $45 \%$ ) under high light exposure compared with larger diatoms $\left(2.13 \times 10^{7} \mu \mathrm{m}^{3}\right)$, whereas PSII repair rates were four-fold slower (Key et al. 2010). The larger cells allocate more of their total cellular protein pool to D1 and have a smaller effective absorption cross-sectional area of PSII (Key et al. 2010). Thus, they are less susceptible to photoinhibition and can better respond to short-term high light exposure. The sea-ice diatoms from this study were intermediate in cell size (1-1.8 $\times 10^{3} \mu \mathrm{m}^{3}$ ) compared with those studied by Key et al. (2010), and they had PSII repair rates close to those of the larger-sized cells. Interestingly, while the D1-protein content of sea-ice diatoms was typical of that measured in other diatom species $\left(0.01-0.03\right.$ pmol D1 $\mu \mathrm{g}^{-1}$ total protein) (Key et al. 2010), the susceptibility to photoinactivation, $\left|\sigma_{i}\right|$, in the sea-ice diatoms was smaller than would be expected based on their cell volume; this is rather comparable to the largest centric diatoms. However, further investigation is needed to confirm any correlation between cell size and photoinactivation in pennate diatoms. It is possible that these sea-ice diatoms have a relatively small antenna size, which would limit light damage (Melis et al. 1999). This would support the observation that with increased light, the preferred strategy adopted by these sea- 
ice diatoms is rapid photoprotection through nonradiative heat dissipation via xanthophyll cycling (K. Petrou unpubl.). This strategy was also found in $F$. cylindrus, which showed almost complete reliance on xanthophyll activity for photoprotection when exposed to high light (Kropuenske et al. 2009). Similarly, many temperate diatoms have displayed a high level of xanthophylldependent NPQ as an immediate photoprotective response (Lavaud et al. 2002, 2004; Ruban et al. 2004). If this remains true for all sea-ice diatoms, by maximizing xanthophyll activity they are able to limit D1-protein inactivation as well as subsequent damage to their photosystems from excess light energy.

This is the first study to measure D1 protein and PSII repair rates in natural populations of Antarctic bottomdwelling sea-ice microalgae exposed to elevated irradiance. While it contradicts the idea that sea-ice algae are obligate shade-adapted photoautotrophs, the discrepancy is likely due to differences in the environmental conditions from which the algae were collected. For example, this study was conducted in the East Antarctic, which has the shortest ice season and the area with least snow accumulation within the Southern Ocean (Arrigo et al. 1998). Consequently, the ice is thinner, and the irradiance is higher than in many other locations around the continent. Any such differences in environmental condition influence the photosynthetic condition of the sea-ice algae. The photosynthetic plasticity to high light exhibited by these natural populations of Antarctic sea-ice diatom communities demonstrates their inherent ability to effectively protect their photosystems from damage even at subzero temperatures. Phytoplankton are often regarded as sentinels of climate change because their rapid population-turnover rates mean populations will respond rapidly to altered environmental conditions. This observed capacity for acclimation to rapid environmental change - specifically increased irradiances - combined with short life cycles and therefore considerable adaptive potential, suggests that the diatom communities observed in this study show potential to adjust to a world with thinner annual sea ice and greater light penetration. However, synergistic effects of increasing irradiance with elevated ocean temperature and ultraviolet irradiation and ocean acidification remain unknown, and these interactions need to be tested in order to fully comprehend their potential to affect sea-ice algae communities.

\section{Acknowledgments}

We thank the captain and crew of the R/V Aurora Australis, chief scientist Anthony Worby, our colleagues involved in the Sea Ice Physics and Ecosystem eXperiment (SIPEX) project, and the Australian Government Antarctic Division for ship time and logistical support. Thanks to Neil Ralph for his expertise with building specialized equipment. Thanks to two anonymous reviewers for their insightful comments that improved the manuscript. Katrina DeZeeuw, Mount Allison University, kindly assisted with immunoquantitations. Antibodies and quantitation standards were a gift from AgriSera.

This work was supported by an Australian Antarctic Science grant (2752) and Australian Research Council Discovery grant (DP0773558) awarded to Peter Ralph. Additional financial support was provided by the Aquatic Photosynthesis Group and Department of Environmental Sciences, University of Technology, Sydney, and the National Research Council of Canada Discovery supported Douglas Campbell and Christopher Brown. Katherina Petrou was supported by an Australian Postgraduate Award and the Commonwealth Scientific and Industrial Research Organisation top-up scholarship.

\section{References}

Allakhverdiev, S. I., And N. Murata. 2004. Environmental stress inhibits the synthesis de novo of proteins involved in the photodamage-repair cycle of photosystem II in Synechocystis sp. PCC 6803. Biochim. Biophys. Acta 1657: 23-32, doi:10.1016/j.bbabio.2004.03.003

Aro, E., I. Virgin, And B. Andersson. 1993. Photoinhibition of photosystem II. Inactivation, protein damage, and turnover. Biochim. Biophys. Acta 1143: 113-134, doi:10.1016/00052728(93)90134-2

Arrigo, K. R., D. Worthen, A. Schnell, and M. P. Lizotte. 1998. Primary production in Southern Ocean waters. J. Geophys. Res. 103: 15,587-15,600.

Brown, C. M., D. A. Campbell, and J. E. Lawrence. 2007. Resource dynamics during infection of Micromonas pusilla by virus MpV-Sp1. Environ. Microbiol. 9: 2720-2727, doi:10.1111/j.1462-2920.2007.01384.x

, J. D. Mackinnon, A. M. Cockshutt, T. Villareal, and D. A. Campbell. 2008. Flux capacities and acclimation costs in Trichodesmium from the Gulf of Mexico. Mar. Biol. 154: 413-422, doi:10.1007/s00227-008-0933-z

Cota, G. F. 1985. Photoadaptation of high Arctic ice algae. Nature 315: 219-222, doi:10.1038/315219a0

Domingues, C. M., J. A. Church, N. J. White, P. J. Gleckler, S. E. Wijffels, P. M. BArker, AND J. R. Dunn. 2008. Improved estimates of upper-ocean warming and multi-decadal sea-level rise. Nature 453: 1090-1093, doi:10.1038/nature07080

Eicken, H. 1992. The role of sea ice in structuring Antarctic ecosystems. Pol. Bio. 12: 3-13.

Ensminger, I., F. Busch, And N. P. A. Hüner. 2006. Photostasis and cold acclimation: Sensing low temperature through photosynthesis. Physiol. Plantarum 126: 28-44, doi:10.1111/ j.1399-3054.2006.00627.x

Giles, K. A., S. W. Laxon, and A. L. Ridout. 2008. Circumpolar thinning of Arctic sea ice following the 2007 record ice extent minimum. Geophys. Res. Lett. 35: L22502, doi:10.1029/ 2008GL035710

Hüner, N. P. A., G. ÖQuist, V. Hurry, M. Krol, S. Falk, And M. Griffith. 1993. Photosynthesis, photoinhibition, and low temperature acclimation in cold-tolerant plants. Photosynth. Res. 37: 19-39, doi:10.1007/BF02185436

- - AND F. SARHAN. 1998. Energy balance and acclimation to light and cold. Trends Plant Sci. 3: 224-230, doi:10.1016/S1360-1385(98)01248-5

Intergovernmental Panel on Climate Change (IPCC). 2007. Climate Change 2007: Synthesis report. R. K. Pachauri and A. Reisinger [eds.], Contribution of Working Groups I, II and III to the Fourth Assessment Report of the Intergovernmental Panel on Climate Change. IPCC, Available from http:॥www.ipcc.ch/pdf/assessment-report/ar4/syr/ar4_syr.pdf

Ivanov, A., P. V. Sane, V. Hurry, M. Krol, D. Sveshnikov, N. P. A. Hüner, And G. ÖQuist. 2003. Low-temperature modulation of the redox properties of the acceptor side of photosystem II: Photoprotection through reaction centre quenching of excess energy. Physiol. Plantarum 119: 376-383, doi:10.1034/j.1399-3054.2003.00225.x 
Key, T., A. McCarthy, D. Campbell, C. Six, S. Roy, and Z. Finkel. 2010. Cell size trade-offs govern light exploitation strategies in marine phytoplankton. Environ. Microbiol 12: 95-104, doi:10.1111/j.1462-2920.2009.02046.x

Kropuenske, L., M. Mills, G. van Dijken, S. Bailey, D. Robinson, N. Welschmeyer, and K. Arrigo. 2009. Photophysiology in two major Southern Ocean phytoplankton taxa: Photoprotection in Phaeocystis antarctica and Fragilariopsis cylindrus. Limnol. Oceanogr. 54: 1176-1196.

Lavaud, J., B. Rousseau, and A. L. Etienne. 2004. General features of photoprotection by energy dissipation in planktonic diatoms (Bacillariophyceae). J. Phycol. 40: 130-37.

- , H. van Gorkom, AND A. L. Etienne. 2002. Influence of the diadinoxanthin pool size on photoprotection in the marine planktonic diatom Phaeodactylum tricornutum. Plant Physiol. 129: 1398-406, doi:10.1104/pp.002014

Levitus, S., J. Antonov, and T. Boyer. 2005. Warming of the world ocean, 1955-2003. Geophys. Res. Lett. 32: L02604, doi:10.1029/2004GL021592

Lizotte, M. P., And C. W. Sullivan. 1991. Photosynthesisirradiance relationships in microalgae associated with Antarctic pack ice: Evidence for in situ activity. Mar. Ecol. Prog. Ser. 71: 175-184, doi:10.3354/meps071175

Mayewsi, P. A., AND others. 2009. State of the Antarctic and Southern Ocean climate system. Rev. Geophys 47: RG1003, doi:10.1029/2007RG000231

Melis, A., J. Neidhardt, and J. Benemann. 1999. Dunaleilla salina (Chlorophyta) with small chlorophyll antenna size exhibit higher photosynthetic productivities and photon use efficiencies than normally pigmented cells. J. Appl. Phycol. 10: 515-525, doi:10.1023/A:1008076231267

Morgan-Kiss, R. M., J. C. Priscu, T. Pocock, L. GudynaiteSavitch, ANd N. P. A. Huner. 2006. Adaptation and acclimation of photosynthetic microorganisms to permanently cold environments. Microbiol. Mol. Biol. R. 70: 222-252, doi:10.1128/MMBR.70.1.222-252.2006

Müller, P., X.-P. Li, AND K. K. NiYOGi. 2001. Non-photochemical quenching. A response to excess light energy. Plant Physiol. 125: 1558-1566, doi:10.1104/pp.125.4.1558

Nagy, L., E. Balint, J. Barber, A. Ringler, K. M. Cook, and P. MAROTI. 1995. Photoinhibition and law of reciprocity in photosynthetic reactions of Synechocystis sp. PCC6803. J. Plant Physiol. 145: 410-441.

Palmisano, A. C., J. B. Soohoo, and C. W. Sullivan. 1985. Photosynthesis-irradiance relationships in sea ice microalgae from McMurdo Sound, Antarctica. J. Phycol. 21: 341-346.

Pocock, T. H., A. Koziak, D. Rosso, S. Falk, and N. P. A. Huner. 2007. Chlamydomonas raudensis (UWO 241), Chlorophyceae, exhibits the capacity for rapid D1 repair in response to chronic photoinhibition at low temperature. J. Phycol. 43: 924-936, doi:10.1111/j.1529-8817.2007.00380.x
Ruban, A., J. Lavaud, B. Rousseau, G. Guglielmi, P. Horton, And A.-L. Etienne. 2004. The super-excess energy dissipation in diatom algae: Comparative analysis with higher plants. Photosynth. Res. 82: 165-175, doi:10.1007/s11120004-1456-1

Schreiber, U. 2004. Pulse-amplitude-modulated (PAM) fluorometry and saturation pulse method, In G. G. Papagiorgiou [ed.], Advances in photosynthesis and respiration. Springer.

Serreze, M. C., M. M. Holland, and J. Stroeve. 2007. Perspectives on the Arctic's shrinking sea-ice cover. Science 315: 1533-1536, doi:10.1126/science.1139426

Singleton, P., and D. Sainsbury. 1994. Dictionary of microbiology and molecular biology, 2nd ed. Wiley.

Six, C., Z. Finkel, A. Irwin, And D. Campbell. 2007. Light variability illuminates niche-partitioning among marine picocyanobacteria. PLoS ONE 2: e1341, doi:10.1371/journal. pone. 0001341

- R. Sherrard, M. Lionard, S. Roy, and D. A. Campbell. 2009. Photosystem II and pigment dynamics among ecotypes of the green alga Ostreococcus. Plant Physiol. 151: 379-390, doi:10.1104/pp.109.140566

Thomas, D. N., M. E. M. Baumann, and M. Gleitz. 1992. Efficiency of carbon assimilation and photoacclimation in a small unicellular Chaetoceros species from the Weddell Sea (Antarctica): Influence of temperature and irradiance. J. Exp. Mar. Biol. Ecol. 157: 195-209, doi:10.1016/00220981(92)90162-4

, and G. S. Dieckmann. 2002. Antarctic sea ice-a habitat for extremophiles. Science 295: 641-644, doi:10.1126/science. 1063391

Turner, J., AND others. 2005. Antarctic climate change during the last 50 years. Int. J. Climatol. 25: 279-294, doi:10.1002/ joc. 1130

, T. A. Lachlan-Cope, S. Colwell, G. J. Marshall, and W. M. Connolley. 2006. Significant warming of the antarctic winter troposphere. Science 311: 1914-1917, doi:10.1126/ science. 1121652

Tyystuarvi, E. 2008. Photoinhibition of photosystem II and photodamage of the oxygen evolving manganese cluster. Coordin. Chem. Rev. 252: 361-376, doi:10.1016/j.ccr. 2007.08.021
Associate editor: Heidi M. Sosik

Received: 15 December 2009 Accepted: 08 February 2010 Amended: 01 March 2010 